\title{
Characterization of Deaths from Cirrhosis of the Liver in Cuba, 1987-2017
}

Plácido Pedroso-Flaquet MD PhD, Karen Alfonso-Sagué, Silvia J. Venero-Fernández MD MS PhD

\begin{abstract}
INTRODUCTION Cirrhosis of the liver is a chronic disease that is widespread and irreversible. It represents the final stage of numerous diseases that affect the liver. By the end of 2017, it was the 11th most common cause of death, with a loss of 41.4 million years of disability-adjusted life years, which represent $2.1 \%$ of the total years of life lost in the global mortality burden. In Cuba, cirrhosis and other chronic liver diseases have been among the top 10 causes of death for several decades, their rates consistently increasing, from 576 deaths in 1970 (6.7 per 100,000 population) to 1738 in 2017 (15.5 per 100,000 population), with a risk of death that is 4.6 times higher in men.
\end{abstract}

OBJECTIVE Characterize deaths from cirrhosis of the liver in Cuba from 1987 to 2017.

METHODS An ecological time-series study was conducted for 1987 to 2017 using information obtained from the mortality database of the Medical Records and Health Statistics Bureau of Cuba's Ministry of Public Health. The study universe consisted of all deceased persons in the country whose underlying cause of death was cirrhosis of the liver. Both general mortality rates and specific mortality were calculated by age group, sex and etiological classification using adjusted and crude rates. Rates were age-adjusted using the direct method, and the population from the 2002 Census of Population and Housing was considered as the standard population. Percentages and means were also calculated according to selected variables and the relative risk of death due to the disease according to sex, age group and etiological

\section{INTRODUCTION}

Liver cirrhosis (LC) is a chronic disease that is widespread and irreversible. It is characterized by fibrosis and formation of regenerative nodules that lead to alteration in the liver's vascular architecture and functionality. It represents the final stage of numerous diseases affecting the liver.[1]

LC is one of the world's main health problems due to its high morbidity and mortality rates. By the end of 2017 , it represented $2.4 \%$ of all deaths worldwide, approximately 1.35 million deaths. It was the 11th cause of death, with a loss of 41.4 million disability-adjusted life years, DALYs, which represent $2.1 \%$ of DALYs in the global mortality burden. LC is related to population growth and aging.[2,3] Different etiological factors are attributed to the prevalence of LC, including alcohol consumption, viral infections and morbid obesity, among others, distributed with wide variability between and within populations.

\section{IMPORTANCE}

This study characterizes mortality due to liver cirrhosis in Cuba (1987-2017), revealing an upward trend that is forecast to continue in coming years. The finding that nonalcoholic cirrhosis has the highest mortality rate suggests a need for more in-depth causality studies. classification. The trend and forecast for mortality rates were estimated for this disease.

RESULTS The crude mortality rate from cirrhosis of the liver was 9.0 per 100,000 population for the period. Those aged $\geq 75$ years had the highest risk of death (48.3 per 100,000 population). The crude and adjusted mortality rates were almost double for men (12.4 vs. 5.6 and 11.7 vs. 5.6 per 100,000 population, respectively), as was the total relative risk of death, which was 2.2 times higher. Nonalcoholic cirrhosis accounted for $71.6 \%$ of deaths. By the end of 2017 , risk of death from cirrhosis had climbed to 14.8 per 100,000 population (adjusted rate: 10.6 per 100,000 population), a signal that mortality had progressively increased over the 31 years analyzed. In addition, forecasts predict that death rates will continue their gradual increase, reaching 19.2 per 100,000 population in 2025 .

CONCLUSIONS Deaths from cirrhosis of the liver constitute a substantial health burden in Cuba. The upward trend and forecast, in addition to increased risk of mortality in men and older adults, are similar to those reported internationally. The finding that most of these deaths result from nonalcoholic cirrhosis should be further studied, as formulation of effective public health strategies depends largely on attaining a better understanding of the etiology, progression and social determinants of the disease.

KEYWORDS Liver cirrhosis, alcoholic liver cirrhosis, fatty liver, mortality, Cuba
In Western and high-income, industrialized countries, alcoholic and nonalcoholic fatty liver diseases are more prevalent than chronic viral hepatitis, while in China and other Asian countries, hepatitis B is more prevalent.[2] Cirrhosis primarily affects men and is common around the fourth or fifth decade of life; however, there are reports of cases in young adults and even in children.[1-3]

For several decades, cirrhosis and other chronic liver diseases have been among the top 10 causes of death in Cuba, deaths and mortality rates rising from 576 deaths in 1970 (6.7 per 100,000 population) to 1738 in 2017 (15.5 per 100,000 population), with a risk of death 4.6 times higher for men.[4,5]

The real magnitude of LC deaths in Cuba is unknown, which is why analyzing LC separately from the larger group of liver-disease deaths is an important step towards understanding its contribution to the mortality rate, data relevant for Cuban public health authorities.

The objective of this study was to characterize deaths due to LC from 1987 to 2017 in Cuba.

\section{METHODS}

We performed an ecological time-series study. The universe included all persons who had died from 1987 to 2017 whose primary cause of death on their death certificate was liver cirrhosis. 


\section{Study variables}

Sex Male, female.

Age Age in years at the time of death. The following age ranges were established: $0-14 ; 15-24 ; 25-39$; 40-49; 50-59; 60-74; $\geq 75$.

$L C$ classification The ninth and tenth revisions of the International Classification of Diseases (ICD-9, ICD10) were used to classify liver cirrhosis. $[6,7]$

- Alcoholic cirrhosis of the liver: Code 571.2 (ICD9 until 2000) and code K70.3 (ICD-10 since 2001).

- Nonalcoholic liver cirrhosis: Code 571.6 for biliary cirrhosis (ICD-9 until 2000) and codes K74.3, K74.4 y K74.5 for primary biliary cirrhosis, secondary biliary cirrhosis, and biliary cirrhosis, unspecified respectively (ICD-10 since 2001). For unspecified nonalcoholic cirrhosis: code 571.5 for cirrhosis of liver without mention of alcohol (ICD-9 until 2000) and K74.6 for other and unspecified cirrhosis of liver (ICD-10 since 2001).

Data collection, processing, and analysis We reviewed the mortality databases of the Ministry of Public Health's Bureau of Medical Records.[8] Population data was obtained from the National Statistics and Information Bureau (ONEI).[9]

We calculated crude and adjusted mortality rates, both global and specific to age group, sex and alcoholic or nonalcoholic etiology. The rates were adjusted for age using the direct method, and the standard population used was from Cuba's 2002 Population and Housing Census.[9] Means and percentages were also calculated according to the selected variables and the relative risk of death from LC according to sex, age group and type of LC.

An LC mortality rate for 2018-2025 was forecast using the two-parameter Holt-Winters model,[10] taking into account the annual frequency of the data. The model's goodness of fit was estimated using the mean square error and performing an analysis of residuals. Excel (Microsoft, USA) was used to develop a database to record results, presenting these in tables and figures.

Ethics The study was approved by the Research Ethics Committee of Cuba's National Institute of Hygiene, Epidemiology and Microbiology (INHEM). The Ministry of Public Health's Medical Records and Health Statistics Bureau authorized use of their data solely for research purposes.

\section{RESULTS}

Deaths due to LC by age group and sex During the period analyzed, there were 31,424 deaths due to LC, for an annual mean of 1014 deaths. The crude mortality rate was 9.0 per 100,000 population (adjusted rate: 8.6). The overall mean age at time of death was 63.0 years (SD 14.2); for men 61.0 years (SD 13.7) and for women, 67.2 years (SD 14.3). At the end of 2017, the risk of death was 14.8 per 100,000 population (adjusted rate: 10.6).

Mortality rates by age group showed a progressive increase with age. In descending order, the most deaths were in the $\geq 75$ group with a crude rate of 48.3 per 100,000 population (adjusted rate: 48.4 ), followed by the $60-74$ age group at 34.4 per 100,000 population (adjusted rate: 32.9 ) and finally the 50-59 age group at 19.4 per 100,000 population (adjusted rate: 18.6) (Table 1).

Men comprised $68.8 \%$ of deaths. The age groups contributing the highest number of deaths for men were the 60-74 and 50-59 age groups, with 7611 and 5515, respectively. These two groups accounted for $60.7 \%$ of deaths among men $(13,126 / 21,635)$. In women, the highest number of deaths occurred in the 60-74 (3933) and $\geq 75$ (3288) age groups, which represented $73.8 \%$ (7221/9789) of female deaths (Table 1).

The crude and adjusted mortality rates for the period were almost double for men, with 12.4 vs. 5.6 and 11.7 vs. 5.6 per 100,000 population respectively (Table 1 ). In men, there was a relative increase in crude mortality over the period of $242.2 \%$ (7.1 to 24.3 per 100,000 population); however, in women, there was a decrease of $3.7 \%$ (5.6 to 5.4 per 100,000 population) (Figure 1).

For both sexes, the risk of death also increased with age. The $\geq 75$ age group exhibited the highest mortality rate for both men and women (Table 1).

Deaths due to LC by etiology The highest risk corresponded to nonalcoholic LC, which accounted for $71.6 \%$ of deaths, while alcoholic LC accounted for $28.4 \%$ (Table 1 ).

The crude and adjusted mortality rates were higher for nonalcoholic cirrhosis (6.5 vs. 2.6 and 6.4 vs. 2.2 per 100,000 population, respectively) and the risk of death from both types of LC were higher among men (Table 1).

In men, mean age at time of death from alcoholic cirrhosis was 57.3 years (SD 11.9), lower than that for nonalcoholic cirrhosis (63.3 years; SD 14.3). In women, death from alcoholic cirrhosis also occurred at a younger age (59.8 years; SD 13.2) than among women with nonalcoholic cirrhosis (67.9 years; SD 14.2). 
Figure 1: Liver cirrhosis mortality rate by year and sex. Cuba, 1987-2017

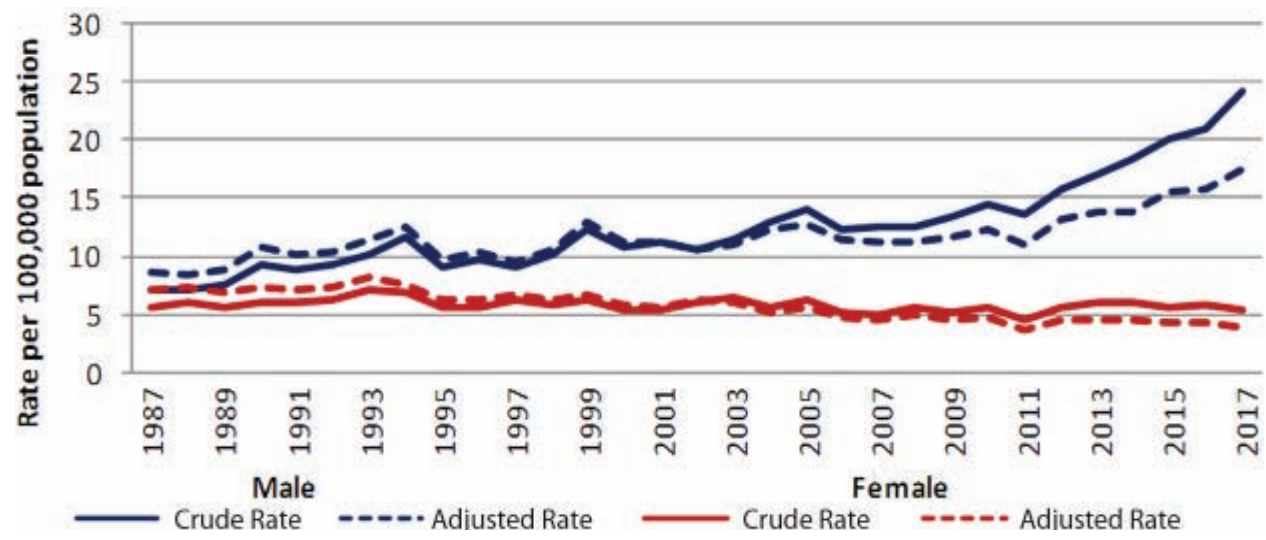

1987 to 14.8 by 2017 (Figure 2), for an increase of $131.2 \%$.

We forecast that LC mortality rates in Cuba will continue to rise gradually, reaching 19.2 (17.7-20.7) per 100,000 population in 2025 .

\section{DISCUSSION}

LC is the end result of a group of chronic liver diseases,[1] representing a major health problem due to the necessity of prolonged treatment and the fact that a liver transplant is, in some cases, the only effective therapy.[11,12]
Relative risk of death from LC in men by age group and disease etiology The relative risk of death from LC was 2.2 times higher in men than in women. Male sex was identified as a risk factor for death in all age groups and for both types of liver cirrhosis, except in persons $\leq 24$ years of age for both types of liver cirrhosis, when no difference was observed for risk of death between the sexes. For alcoholic cirrhosis, men's risk was 10.8 times higher than women's and age groups between 25 and 59 years were at higher risk. The relative risk of death for nonalcoholic cirrhosis was only 1.5 times higher in men than in women. In the 40-49 age group, men were 3.2 times more likely to die of nonalcoholic liver cirrhosis than women (Table 2).

LC mortality forecasting Mortality rates progressively increased during the 31 years analyzed. In terms of crude rates, LC mortality experienced an increase from 6.4 per 100,000 population in

Table 2: Relative risk of death from alcoholic and nonalcoholic liver cirrhosis in men by age group. Cuba, 1987-2017*

\begin{tabular}{|l|r|r|r|}
\hline & \multicolumn{2}{|c|}{ Type of cirrhosis } & \\
\hline Age group (in years) & Alcoholic & Nonalcoholic & Total \\
\hline $0-14$ & 0.0 & 0.7 & 0.7 \\
\hline $15-24$ & 0.0 & 0.9 & 1.0 \\
\hline $25-39$ & 11.5 & 2.3 & 3.5 \\
\hline $40-49$ & 12.4 & 3.2 & 5.2 \\
\hline $50-59$ & 12.1 & 2.3 & 3.6 \\
\hline $60-74$ & 10.7 & 1.4 & 1.9 \\
\hline$\geq 75$ & 6.1 & 1.0 & 1.2 \\
\hline Total & 10.8 & 1.5 & 2.2 \\
\hline
\end{tabular}

*women were used as a reference group

Figure 2: Liver cirrhosis mortality rate and forecast. Cuba, 1987-2025

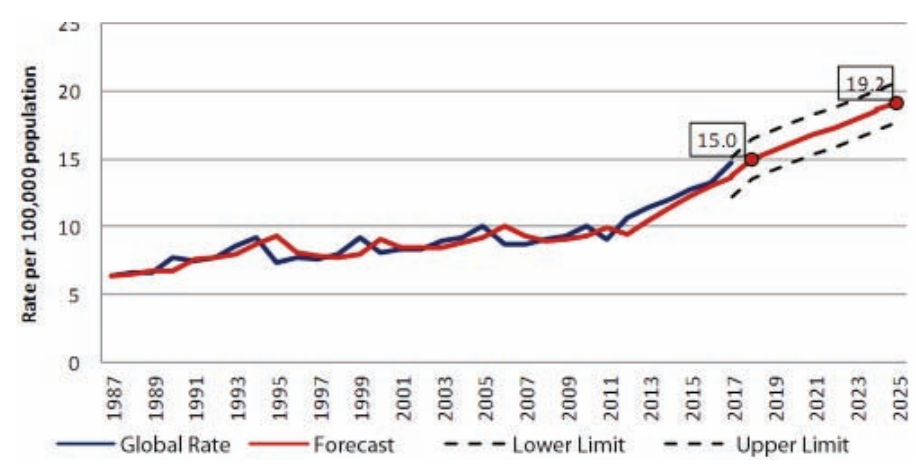

We could not compare the crude and adjusted mortality rates with other estimates, because the sources available only contained information for specific years. The risk of death in Cuba in 2017 was similar to forecasts released by international bodies and published epidemiological studies.[2,3,12] One recent study on burden of mortality, injuries and risk factors for LC predicted a standardized global mortality rate for 2017 of 16.5 (15.8-18.1) per 100,000 population, with a lower value in high-income countries (10.1 per 100,000 population) and a higher value in the broad region of Sub-Saharan Africa (32.2 per 100,000 population). In that study, Caribbean countries' predicted values were 10-20 per 100,000 population.[2]

The progressive increase in risk of death with age in both sexes was the expected result, as also found in other countries, evidenced by a recent systematic review.[2] In Cuba, characteristics of the Cuban health care system (universal, accessible, free of charge to patients), as well as newer medical treatments, may have contributed to this finding; these factors facilitate more timely diagnoses with proper care and followup, and consequently, greater chronicity and death at older ages.[11,13] Various studies conducted in different provinces of the country confirm this conjecture.[14-17] Cuba's quickly aging population[5] will undoubtably contribute to this increased risk.

The greatest risk of death in men is consistent with extensive medical literature at the national and international levels and can be explained by alcohol addiction.[1-3,14-20] In Barcelona and the United Kingdom, studies conducted in urban and rural areas demonstrate the presence of socioeconomic inequality in the male population with cirrhosis, which is correlated with low levels of education and socioeconomically disadvantaged areas, which in turn may be related to alcohol consumption.[18,19]

The main causes of LC are chronic consumption of alcohol and chronic viral disease, primarily from hepatitis $\mathrm{C}$ virus $(\mathrm{HCV})$ and hepatitis B virus (HBV), which taken together account for $90 \%$ of all cirrhosis cases.[1-3] In Cuba, the widespread prevalence of harmful alcohol use (5\%) and alcohol dependence (3\%) from 1995 to 2010 was similar to that of other countries, and these values have not changed over time.[18-22] Worldwide, half of LC deaths are attributed to alcoholism, with greater frequency among men. Therefore, in our study, it was surprising to find that nonalcoholic-LC causes were more prevalent in men, and that overall, 7 deaths in 10 corresponded to nonalcoholic cirrhosis.[2,3] 
Several national studies have identified infectious causes of LC in men, primarily HBV.[14,17] However, etiology of nonalcoholic cirrhosis can also be noninfectious.[1,2] In Cuba, various causes of nonalcoholic LC have been reported in different provinces,[14-17] which emphasizes the need for further research.

One factor that may influence the predominance of nonalcoholic LC in this population is obesity, which is recognized as a risk factor for nonalcoholic steatohepatitis (fatty liver disease) and consequent LC. From 2001 to 2010, Cuba experienced an increase in obesity prevalence (from $11.8 \%$ to $14.8 \%$ ). In addition, nonalcoholic fatty liver in advanced stages of the disease were reported in samples from liver biopsies.[20,23] Varying degrees of malnutrition observed in advanced stages of LC are also associated with its onset and prognosis.[24]

Regarding infection, universal vaccination against hepatitis B virus began in Cuba in 1992, with the application of a Cuban recombinant vaccine (Heberbiovac-HB). While over two decades separate this intervention from the end of our study period, it can still be assumed that a portion of LC deaths we found may have been from infections acquired before availability of vaccination.[25] Cuba has not been spared from the silent HCV epidemic that occurred from 1960 to 1989 , the year when the virus was identified.[26] There are no vaccines for $\mathrm{HCV}$, only treatments, which may cure up to $95 \%$ of cases, but which are expensive and have not been available in the entire Cuban health system. HCV infection has been identified as a public health problem in Cuba since 1990 after the first national serology study was conducted in blood banks, finding $0.8 \%$ positivity. This has increased to about $2 \%$, a value similar to global HCV prevalence $(2.3 \%)$ but higher than prevalence in the Caribbean as a whole (1.5\%).[3,27-29]

The increase in LC mortality rates over the course of the study period was an expected result, since reports from prior stud- ies in western and central Cuba had pointed to such a rise, and increased presence of important variables contributing to higher LC rates in the Cuban population were also recorded.[15,17,20] However, this finding was in contrast to global data,[2,3] which showed a decrease in LC mortality rates standardized by age in both sexes, the decrease more pronounced in men. Interventions to reduce alcohol and tobacco use, along with better treatments, have contributed to this trend.[2,3]

It would be expected that the trend of increasing LC in Cuba would continue if exposure to risk factors continues to increase. However, causality studies are needed to identify the social determinants with the greatest impact on the development of LC and its mortality rate in Cuba. Several studies on the burden of LC suggest that the causal factors with the greatest impact are those related to lifestyle (alcohol addiction and obesity) and infections, which may increase in the future in some countries. $[3,30]$

One important limitation of this study was the inability to break down nonalcoholic cirrhosis into different types to understand the incidence of each subtype.

\section{CONCLUSIONS}

Liver cirrhosis mortality represents a substantial health burden in Cuba and has increased since 1987. This increase is also evident in forecasts for the disease, especially for men and older adults, the latter a particularly important factor given the aging of the Cuban population. The predominance of nonalcoholic cirrhosis should be the object of future study.

\section{ACKNOWLEDGMENTS}

We would like to thank Dr Ramón Suárez-Medina for his contribution to the organization of the database. $-1 /$ -

\section{REFERENCES}

1. Ginés P, Arroyo V. Cirrosis hepática. In: Farre ras R, editor. Medicina Interna. 17th ed. Madrid Elsevier; 2012. p. 314-9. Spanish.

2. GBD 2017 Cirrhosis Collaborators. The global regional, and national burden of cirrhosis by cause in 195 countries and territories, 19902017: a systematic analysis for the Global Burden of Disease Study 2017. Lancet Gastroenterol Hepatol. 2020 Mar 1;5(3):245-66.

3. Asrani SK, Devarbhavi H, Eaton J, Kamath PS. Burden of liver diseases in the world. J Hepatol [Internet]. 2019 [cited 2020 Mar 11];70(1):151-71. Available at: https://www.journal-of-hepatology .eu/article/S0168-8278(18)32388-2/abstract

4. National Health Statistics and Medical Records Division (CU). Anuario Estadístico de Salud 1970. Havana: Ministry of Public Health (CU); 1970. Spanish.

5. National Health Statistics and Medical Records Division (CU). Anuario Estadístico de Salud 2017 [Internet]. Havana: Ministry of Public Health (CU); 2018 Apr [cited 2020 Mar 15]. 206 p. Available at: http://files.sld.cu/dne/files/2017/05/anua rio-2017-esp-e.pdf. Spanish.

6. Pan American Health Organization. Manual de la Clasificación Internacional de Enfermedades, Traumatismos, y Causas de Defunción CIE-9. Vol. 2 [Internet]. Washington, D.C.: Pan American Health Organization; 2003 [cited 2020 Mar 8]. 173 p. Available at: http://ais.paho.org/classifications/Chapters/pdf/ Volume2.pdf. Spanish.
7. Pan American Health Organization. Clasificación Estadística Internacional de Enfermedades y Problemas Relacionados con la Salud. Décima revisión. (CIE-10) Manual de Instrucciones. Décima revisión. Vol. 1. Washington, D.C.: Pan American Health Organization; 2003 [cited 2020 Mar 8]. 1177 p. Available at: https://iris.paho.org/ bitstream/handle/10665.2/6282/Volume1.pdf. Spanish.

8. INFOMED [Internet]. Havana: Ministry of Public Health (CU); c2020. Publicaciones. Health Care Situation in Cuba. Basic Indicators; [cited 2020 Mar 8]. Available at: https://temas.sld.cu/estadis ticassalud/publicaciones-2/health-care-situation -in-cuba-basic-indicators/. Spanish.

9. National Bureau of Statistics and Information (CU). Censo Nacional de Población y Viviendas. Havana:National Bureau of Statistics and Information (CU); 2002. Spanish.

10. Chatfield $\mathrm{C}$. The analysis of time series: an introduction. 6th ed. Florida: Chapman \& Hall; 2004.

11. Arús Soler E, Pérez Brioso NA, Parrilla Delgado M, Domínguez Álvarez C. Antifibrotic effect of recombinant interferon alfa $2 b$ in liver cirrhosis caused by virus B or C. Rev Cubana Med [Internet]. 2005 May-Aug [cited 2020 Mar 11]:44(34). Available at: http://scielo.sld.cu/scielo .php?script=sci_arttext\&pid=S0034-752320 05000400008\&lng=es. Spanish.

12. Ramírez-Soto M, Guevara-Cuadros J, HuichiAtamari M. Mortalidad por hepatocarcinoma y cirrosis hepática en Apurímac: 2007-2010. Rev
Perú Epidemiol [Internet]. 2012 Jan-Apr [cited 2017 Nov 12];16(1):1-5. Available at: http://www redalyc.org/pdf/2031/203124341008.pdf. Spanish.

13. Ojeda Morales R, Más Bermejo P, Castell-Florit Serrate P, Arocha Mariño C, Valdivia Onega NC, Druyet Castillo D, et al.. Transformaciones en el sistema de salud en Cuba y estrategias actuales para su consolidación y sostenibilidad. Rev Panam Salud Pública. 2018 Apr 24;42:e25. DOI: 10.26633/RPSP.2018.25. Spanish

14. Castellanos Suárez J, Infante Velázquez $M$ Pérez Lorenzo M, Umpiérrez García I, Fernández Báez A. Caracterización clínica de pacientes con cirrosis hepática en el Hospital Militar Docente Dr. Mario Muñoz, de Matanzas. Rev Méd Electrón [Internet]. 2012 Nov-Dec [cited 2020 Mar 16];34(6):624-37. Available at: http:// scielo.sld.cu/scielo.php?script=sci_arttext\&pid =S1684-18242012000600001. Spanish.

15. Fajardo González MH, Arce Núñez M, Medina Garrido Y, Esteva Carral L, Osorio Pagola MF. Comportamiento de la cirrosis hepática en el hospital "Arnaldo Milián Castro" de julio de 2007 a marzo de 2009. MediSur [Internet]. 2010 Jul-Aug [cited 2020 Feb 12];8(4):40-8. Available at: http://scielo .sld.cu/scielo.php?script=sci_arttext\&pid=S1727 -897X2010000400007. Spanish.

16. Roque Lozano JA, Sauchay Romero L, Rodríguez Chala HE. Caracterización de mortalidad por cirrosis hepática en el Hospital "Julio Trigo López”. 2012 a 2016. Rev Cubana Tecnol Salud [Internet]. 2019 Apr-Jun [cited 2020 Apr 
3];10(2):35-43. Available at: http://www.revtec nologia.sld.cu/index.php/tec/article/view/1310. Spanish.

17. Torreblanca Xiques A, Fonseca Chong L. Caracterización de los pacientes con cirrosis hepática atendidos en Las Tunas. Rev Electrón Dr. Zoilo Marinello [Internet]. 2014 [cited 2020 Mar 31];39(12). Available at: http://revzoilomarinello .sld.cu/index.php/zmv/article/view/121. Spanish.

18. Dalmau-Bueno A, García-Altés A, Mari-Dell'Olmo $M$, Pérez K, Espelt A, Kunst AE, et al. Trends in socio-economic inequalities in cirrhosis mortality in an urban area of Southern Europe: a multilevel approach. J Epidemiol Comm Health [Internet]. 2010 Aug [cited 2020 Mar 31];64(8):720-7. Available at: https://www.jstor.org/stable/40794069

19. Erskine S, Maheswaran R, Pearson T, Demrmot G. Socioeconomic deprivation, urban-rural location and alcohol-related mortality in England and Wales. BMC Pub Health [Internet]. 2010 Feb 25 [cited 2020 Feb 13];10:99. Available at: https://bmcpublichealth.biomedcentral.com/ar ticles/10.1186/1471-2458-10-99

20. Colectivo de autores. III Encuesta Nacional de Factores de Riesgo y Actividades Preventivas de Enfermedades No Transmisibles 2010-2011 [Internet]. Havana: Editorial Ciencias Médicas; 2014 [cited 2020 Mar 12]. Available at: https://especia lidades.sld.cu/higienepidemiologia/2014/08/23/ iii-encuesta-nacional-de-factores-de-riesgo-y -actividades-preventivas-de-enfermedades-no -trasmisibles-cuba-2010-2011/. Spanish.

21. World Health Organization. Informe Mundial de Situación sobre Alcohol y Salud 2018. Resumen. (OPS/NMH/19-012). Licencia: CC BY-NC-SA 3.0 IGO. Washington, D.C.: Pan American Health Organization; 2019. Spanish.

22. Rehm J, Samokhvalov AV, Shield KD. Global burden of alcoholic liver diseases. J Hepatol [Internet]. 2013 Jul 1 [cited 2020 Mar 8];59(1):160-8. Available at: https://www.journal-of-hepatology .eu/article/s0168-8278(13)00184-0/fulltext

23. Pérez Lorenzo $M$, Duarte Castillo $N$, Montero González T, Franco Estrada S, Winograd
Lay R, Brizuela Quintanilla RA. Prevalencia del hígado graso no alcohólico en muestras de biopsias hepáticas. Rev Cub Med Mil [Internet]. 2006 Oct-Dec [cited 2020 Mar 11];35(4). Available at: http://scielo.sld.cu/ scielo.php?script=sci arttext\&pid=S0138 $-65572006000400006 \&$ lng $=e s$. Spanish

24. Castellanos Fernández MI. La importancia de la desnutrición en el pronóstico del paciente con cirrosis hepática [thesis] [Internet]. [Havana]: Universidad de Ciencias Médicas de La Habana. Facultad de Ciencias Médicas "General Calixto García"; 2017 [cited 2020 Mar 8]. 156 p. Available at: http://tesis.sld.cu/index .php?P=FullRecord\&ID=391. Spanish

25. Pedroso Flaquet P. Aportes a la evaluación de la vacuna recombinante cubana contra la hepatitis B [thesis] [Internet]. [Havana]: "Pedro Kourí" Institute of Tropical Medicine (CU); 2009 [cited 2020 Mar 8]. 142 p. Available at: http://tesis.sld .cu/index.php?P=FullRecord\&ID=496. Spanish.

26. Lozano $R$, Naghavi $M$, Foreman $K$, Lim $S$, Shibuya K, Aboyans V, et al. Global and regional mortality from 235 causes of death for 20 age groups in 1990 and 2010: a systematic analysis for the Global Burden of Disease Study 2010. Lancet [Internet]. 2012 Dec 15 [cited 2020 Mar 8];380(9859):2095-128. Available at: https:// www.ncbi.nlm.nih.gov/pubmed/23245604

27. Padrón G, Arús E, Roca J, Viña A, Lemus G, Bacallao J. The hepatitis $C$ in Cuba: prevalence, antibody pattern, genotype and risk factor. Hepatology. 1994;19(4):141.

28. Vázquez Torres Y, Infante Velázquez M, Miranda Gómez O, Vázquez Torres YC, Vázquez Anovega $\mathrm{H}$, Torres Sánchez $\mathrm{C}$, et al. Detección de anticuerpos contra el virus de la hepatitis C en donantes de sangre voluntarios. Rev Cubana Med Gen Integr [Internet]. 2017 Oct-Dec [cited 2020 Apr 2];35(4). Available at: http://scielo.sld .cu/scielo.php?script=sci_arttext\&pid=S0864 $-21252017000400002 \&$ lng=es. Spanish.

29. Petruzziello A, Marigliano S, Loquercio G, Cozzolino A, Cacciapuoti C. Global epidemiology of hepatitis $C$ virus infection: an up-date of the distribution and circulation of hepatitis $\mathrm{C}$ virus genotypes. World J Gastroenterol [Internet]. 2016 Sep 14 [cited 2019 Nov 2];22(34):7824-40. Available at: https://www.ncbi.nlm.nih.gov/pmc/ articles/PMC5016383/

30. Younossi Z, Tacke F, Arrese M, Chander Sharma B, Mostafa I, Bugianesi E, et al. Global perspectives on nonalcoholic fatty liver disease and nonalcoholic steatohepatitis. Hepatology [Internet] 2019;69(6):2672-82. Available at: https://www .ncbi.nlm.nih.gov/pubmed/30179269

\section{THE AUTHORS}

Plácido Pedroso-Flaquet (Corresponding author: ppf@infomed.sld.cu), physician specializing in epidemiology with a doctorate in medical sciences. Full professor and senior researcher, Unit for Health Promotion and Disease Prevention (PROSALUD), Ministry of Public Health, Havana, Cuba. https://orcid.org/0000-0002 $-9340-7410$

Karen Alfonso-Sagué, mathematician, adjunct researcher, National Institute of Hygiene, Epidemiology and Microbiology (INHEM), Havana, Cuba. https://orcid.org/0000-0001-6621-013X

Silvia Josefina Venero-Fernández, physician specializing in family medicine and epidemiology, with a master's degree in environmental health and a doctorate in health sciences. Associate researcher and associate professor, INHEM, Havana, Cuba. https://orcid.org/0000 $-0002-5661-9043$

Submitted: December 2, 2019

Approved for publication: September 20, 2020 Disclosures: None 